\title{
'He Might Come Back': Views on Sámi Cultural and Linguistic Revitalisation from Finland
}

\author{
Tero Mustonen
}

One of the Sámi traditional knowledge holders of his time, the late Jouni Antti Vuomajoki (1917-99) from the Deatnu River area in Utsjoki, Finland, was walking in the forest close to his home community.

He saw a stone object resembling, and most likely it was, an ancient stone axe on the ground.

Upon returning home, he mentioned this discovery to his son, Niilo. Niilo suggested that they contact the authorities or the National Board of Antiquities to register this Stone Age archaeological find.

Jouni Antti refused.

Niilo asked, 'Why not?'

Jouni Antti replied, 'Because one day ... he who left the axe there ... one day he might come back looking for it at the spot where he left it'. ${ }^{1}$

${ }^{1}$ The author is grateful to Niilo Vuomajoki for passing on this oral history, and allowing it to be published here. The Vuomajoki family has reviewed the draft of the article and approved it. 
The Sámi are constitutionally recognised Indigenous peoples in Finland. There are three Sámi ethnolinguistic groups in Finland, each with specific territorial engagements to their places-the North Sámi, numbering the most; the Inari Sámi, who only live in the territory of Finland; and the Skolt Sámi, who belong to the larger Eastern Sámi cultural sphere.

While Finland is, at the time of writing, in December 2014, contemplating the ratification of the International Labour Organization (ILO) 169 Convention on Indigenous rights to the lands and waters, there are many issues which are still in need of urgent solutions. The Snowchange Cooperative, a Finnish cultural and scientific organisation, has been working with Sámi communities for 15 years. The partnerships with the Sámi have contributed to the governmental Arctic Council assessments such as the Arctic Biodiversity Assessment and Arctic Climate Impact Assessment in addition to authoring several scientific papers and monographs about the situation in these communities. While these scientific reports have made the Sámi situation in Finland more visible, the most central challenges, which are at the same time the most urgent, remain. These challenges have to do with cultural and linguistic revitalisation.

The opening story of this article conveys part of the oral history of the Vuomajoki family, where the old man Jouni Antti sees a stone axe and leaves it to be. Younger generations challenge this, calling for a report to the authorities. Jouni Antti, being immersed in the Sámi tradition, decides otherwise. No matter how we interpret the decisions and choices of the elder Vuomajoki, we are left with a realisation that the Sámi have their own senses of the world, of time, place and events that can be challenging to understand from outside the culture.

However, these stories also convey a profound and sensitive engagement with the landscape and all of its elements—-seen and the unseen — and more importantly, ways of being with it. In essence, they result from decisions flowing from and guided by Sámi tradition. Furthermore, the Sámi language, traditional mind, livelihoods, culture and life itself exist in a deep and holistic engagement with its places-each to their own respectively. Therefore, the revitalisation efforts need to reflect this realisation-a view the nation-state governments in their compartmentalised categories of decision-making often fail to understand. 
Across the Finnish Sámi areas a successful model of linguistic revitalisation has been built on the Mãori language nests. The idea behind this action is that children, from the earliest age possible, are fully immersed in their Indigenous languages as much as possible. Often parents, who are also (re)learning the Sámi language, join the nests while children are learning, to boost their own skills. A struggle that remains is that funds for these language nests are negotiated on a yearly basis and, every year, major cuts are proposed, leaving it to the Sámi Parliament to defend and repeatedly justify why the annual funds are needed.

The strategically most advanced and deepest-reaching effort underway in Finland in terms of cultural and linguistic revitalisation amongst the Eastern Sámi is the Neiden/Näätämö River Collaborative Management Process (Mustonen and Feodoroff 2014). It is located, with various manifestations, in the Neiden watershed. This project began as cooperation between the Skolt Sámi and other Eastern Sámi communities, the Sámi Council, Indigenous Peoples' Climate Change Assessment (IPCCA, at United Nations University - UNU) Traditional Knowledge Initiative, and the Saa'mi Nu'ett cultural organisation.

The project has been a part of the international IPCCA initiative that is being developed and coordinated by a Peru-based Indigenous nonprofit organisation, Asociación ANDES, and supported by UNU. By applying the IPCCA methodology of community-led self-reflection, evaluation and future visioning based on local world views and traditional knowledge, the Sevettijärvi Skolts developed a community-based climate change adaptation plan. Out of this process, a collective consensus has emerged that the climate change challenges faced by the reindeer, while significant, are manageable given the present-day nature of reindeer herding. Instead, the Skolt Sámi identified their customary salmon fishery, the other half of their traditional subsistence and cultural identity, as a much greater concern.

As a result, the Snowchange-Skolt partnership has chosen to focus their climate change adaptation efforts on enhancing the resilience of the Skolts' traditional salmon fishery along the Nääämö River. Scientists have also identified that the stocks of Atlantic salmon have diminished in the past 30 years, mostly due to fishing and human alterations in the habitats of the fish. Therefore the focus on the salmon is justified as concern is shared both in Indigenous societies and the scientific community. Now in its fifth year, the comanagement activities have spread to another Eastern 
Sámi home river, the Ponoi, in the Murmansk region, Russia. A major cultural-linguistic digital database and maps have been developed with international partners across the world. Earlier in 2014, the Skolts released a short film about the all-encompassing efforts underway, as part of the process of registering the Skolt Archives into the UNESCO Memory of the World Register (SAKK Medialinja 2014). Materials from the river project have been actively used in the language nest work of the Skolts.

Most profoundly, the Sámi have invited others to join. The collaborative management plan and project along the Neiden River includes local knowledge of the Kven Finnish minority living on the Norwegian side of the river, as well as scientists, local Finnish peoples and authorities. Therefore, it has emerged as a potential vehicle for a peace process between the state and the Skolts, to address decades of a colonial rule, leaving them behind and exploring a future of joint management of the river, so that all cultures, all ecosystems, and the landscapes, can survive the twenty-first century. As recently as September 2014, the Skolts hosted a major international 'Festival of Northern Fishing Traditions' (Mustonen and Raygorodetsky 2014; Pecl et al. 2017), another success and a demonstration of how traditional culture, language and peoples can make a powerful comeback when all of these elements work together in the same direction.

When Jouni Antti Vuomajoki found the stone axe in the forest, it became a crucial event for him. This is a key concept in many Indigenous societies of the Eurasian North from the Sámi to the Kolyma River and the shores of Chukotka in northeast Siberia. These events, which are often documented, as 'Indigenous observations' should be read in the context of a many-layered spherical reality. An event, when it occurs, is often interpreted in the Indigenous culture against the immediate surroundings, but also against the mythical-spiritual deeper layers of Indigenous mind and memory. An event can be reflected on in many ways; it may contain links and repetitions to mythical times, which are passed down as oral narratives and histories. It may even exist simultaneously in myth-time and the present.

Listening to the voices of the Snowchange community work across Eurasia in 2014, from Swedish Sámi to the Skolts, to Murmansk, onwards to the Khanty and Mansi in Western Siberia, all the way to the Evenk, Yukaghir and Chukchi of Sakha-Yakutia, northeast Siberia, a common 
realisation is emerging - now is the event, now is the hour of change, now is the moment when the future of these societies, languages and cultures is decided.

If the Indigenous leaders across the world fail now in their efforts, and the nation-states and corporations infringing on their lands continue their relentless assault, we will witness a massive collapse of both natural and cultural diversity in the imminent future. Therefore, the time has come to act today, for the elders of tomorrow, to make sure these peoples, their lands and communities, and their distinct societies survive this century.

\section{References}

Mustonen, Tero and Pauliina Feodoroff. 2014. 'Report on the Collaborative Management Workshops in Kola Peninsula, Russia and along the Näätämö River Catchment Area, Finland - Working Report from 2013-2014'. Snowchange Report \#3. Online: www.snowchange.org/pages/wp-content/ uploads/2014/05/Snowchange-Ponoi-and-Neiden-2013-Report.pdf (accessed 2 July 2018).

Mustonen, Tero and Gleb Raygorodetsky. 2014. 'Fishers of Eurasian Arctic come together in a time of war'. Our World, 10 July. Online: ourworld.unu.edu/ en/fishers-of-eurasian-arctic-come-together-in-a-time-of-war (accessed 2 July 2018).

Pecl, Gretta, Miguel Aroújo, Julia Blanchard, Timothy C Bonebrake, I-Ching Chen, et al. 2017. 'Biodiversity redistribution under climate change: Impacts on ecosystems and human well-being'. Science 355(6332): eaai9214.

SAKK Medialinja. 2014. The Skolt Sámi Archive. Online: www.youtube.com/ watch? $=q I 2 J-q Q R U r s$ (accessed 2 July 2018).

Snowchange Cooperative. 2018. Online: www.snowchange.org (accessed 2 July 2018). 
This text is taken from Indigenous Efflorescence: Beyond Revitalisation in Sapmi and Ainu Mosir, edited by Gerald Roche, Hiroshi Maruyama and Åsa Virdi Kroik, published 2018 by ANU Press, The Australian National University, Canberra, Australia.

doi.org/10.22459/IE.2018.03 